\title{
Penggunaan Metode Field Trip Mangrove Cagar Alam Pulau Dua Terhadap Penguasaan Konsep Siswa
}

\author{
Dwi Ratnasari $^{1 *}$, RR Hertien Koosbandiah ${ }^{2}$ dan Bambang Supriatno ${ }^{2}$ \\ ${ }^{1}$ Jurusan Pendidikan Biologi, FKIP, Universitas Sultan Ageng Tirtayasa \\ ${ }^{2}$ Pendidikan Biologi, Pascasarjana, Universitas Pendidikan Indonesia \\ *Corresponding e-mail: dwiratnasari1988@gmail.com
}

Received: 25 Oktober 2017

Accepted: 1 November 2017

Published: November 2017

\begin{abstract}
The Use of Field Trip Method of Mangrove in Pulau Dua Sanctuary on The Student's Concept Mastery. This study aimed to analyze the field trip method of Mangrove in Pulau Dua Nature Reserve on students' concepts mastery. The research used quasi experiment method with The Matching Only Posttest Only Control Group Design. This research used experimental class and control class with research subject of $X$ grade student in SMA Negeri A of Serang-Banten City. Data were obtained from concepts mastery test and questionnaire of students "responses regarding the implementation of learning. The results showed that the use of field trip method of Mangrove in Pulau Dua Nature Reserve on students' concepts mastery is higher than control class.
\end{abstract}

Keywords: Mangrove Pulau Dua Nature Reserve, Field Trip, Concept Mastery

\begin{abstract}
Abstrak: Penggunaan Metode Field Trip Mangrove Cagar Alam Pulau Dua Terhadap Penguasaan Konsep Siswa. Studi ini bertujuan untuk menganalisis metode field trip Mangrove Cagar Alam Pulau Dua terhadap penguasaan konsep siswa.Metode penelitian yang digunakan adalah quasi eksperimen dengan desain penelitian The Matching Only Posttest Only Control Group Design. Penelitian ini menggunakan kelas eksperimen dan kelas kontrol dengan subjek penelitian siswa kelas $\mathrm{X}$ di SMA Negeri A Kota Serang-Banten. Data diperoleh dari soal penguasaan konsep dan angket tanggapan siswa mengenai keterlaksanaan pembelajaran. Hasil penelitian menunjukkan bahwa penggunaan metode field trip mangrove Cagar Alam Pulau Dua terhadap penguasaan konsep siswalebih tinggi dari kelas kontrol.
\end{abstract}

Kata kunci: Mangrove Cagar Alam Pulau Dua, Field Trip, Penguasaan Konsep

\section{PENDAHULUAN}

Biologi merupakan salah satu mata pelajaran yang memerlukan interaksi dan pengalaman langsung dalam kegiatan pembelajaran. Biologi merupakan ilmu pengetahuan alam yang di dalamnya membahas mengenai makhluk hidup, lingkungan, dan interaksi dengan lingkungan yang sifatnya faktual sehingga dalam mempelajarinya diperlukan kegiatan belajar yang mampu mendorong siswa 
untuk melakukan pengamatan dan pengambilan data secara langsung. Menurut Aqib \& Rohmanto (2007), sains mempelajari alam yang mencakup proses perolehan pengetahuan melalui pengamatan, penggalian, penelitian dan penyampaian informasi dan produk (pengetahuan ilmiah dan terapannya) yang diperoleh melalui berpikir dan bekerja secara ilmiah.

Salah satu potensi lokal yang dapat dimanfaatkan dalam pembelajaran biologi adalah Cagar Alam Pulau Dua. Cagar Alam Pulau Dua memiliki karakteristik ekosistem yang bernilai penting untuk berbagai jenis burung dan mangrove. Menurut Takandjandji \& Kwatrina (2011) dalam perkembangannya Cagar Alam Pulau Dua telah mengalami perubahan-perubahan dari segi fisik, biotik dan sosial budaya. Perubahan yang terjadi disebabkan peristiwa alam dan ada juga yang merupakan dampak dari kegiatan manusia yang mengakibatkan perubahan pada pantai, serta rusaknya beberapa bagian vegetasi mangrove.

Pemanfaatan potensi lokal dapat dilakukan siswa dengan menggunakan metode field trip. Metode field trip merupakan metode belajar yang digunakan dengan membawa langsung siswa ke suatu lokasi untuk melihat secara langsung objek yang ada di dalamnya, sehingga siswa lebih memahami materi dan teori yang telah diperolehnya. Senada dengan itu Djamarah (2005) menyatakan bahwa siswa akan lebih tertarik dan mendalami pelajaran jika belajar langsung di lingkungan dalam kehidupan nyata.

SMA Negeri A kota Serang-Banten merupakan sekolah yang lokasinya dekat dengan Cagar Alam Pulau Dua. Siswa belum pernah melakukan pengamatan langsung keadaan mangrove di Cagar Alam Pulau Dua. Terjadinya perubahan dan pencemaran lingkungan di Cagar Alam Pulau Dua penting untuk diketahui oleh siswa, agar siswa lebih memahami konsep pencemaran lingkungan yang telah dipelajari melalui interaksi secara langsung dan diharapkan akan tumbuh sikap kesadaran serta kepedulian siswa terhadap lingkungan sekitar. Oleh karena itu perlu dilakukan penelitian mengenai: "Penggunaan Metode Field Trip Mangrove Cagar Alam Pulau Dua Terhadap Penguasaan Konsep Siswa".

\section{METODE}

Metode penelitian yang digunakan adalah metode eksperimen semu (quasi experiment) dengan desain penelitian The Matching Posttest Only - Control Group Design. Populasi dalam penelitian ini siswa kelas X (sepuluh) SMA Negeri A Kota Serang, Banten dengan pengambilan sampel secara purposive sampling. Penelitian menggunakan kelas kontrol yang melakukan kegiatan pembelajaran tentang pencemaran lingkungan di dalam kelas dan kelas eksperimen yang melakukan kegiatan pembelajaran melalui kegiatan field trip mangrove Cagar Alam Pulau Dua.

Instrumen penelitian berupa soal penguasaan konsep siswa pada konsep pencemaran lingkungan dan angket tanggapan siswa mengenai keterlaksanaan pembelajaran.

Prosedur penelitian dilakukan melalui beberapa tahapan, diantaranya adalah tahap persiapan, tahap pelaksanaan, dan tahap pengolahan serta analisis data. Analisis data soal penguasaan konsep dilakukan melalui uji normalitas, homogenitas dan tahap menguji hipotesis penelitian.

\section{HASIL DAN PEMBAHASAN}

Penguasaan konsep diukur setelah siswa melakukan kegiatan field trip untuk kelas eksperimen dan setelah pembelajaran di dalam kelas untuk kelas kontrol. Penguasaan konsep yang diukurpada tingkat kognitifC2 (memahami). Data yang diperoleh sebagai berikut: 
- Kelas Eksperimen Kelas Kontrol

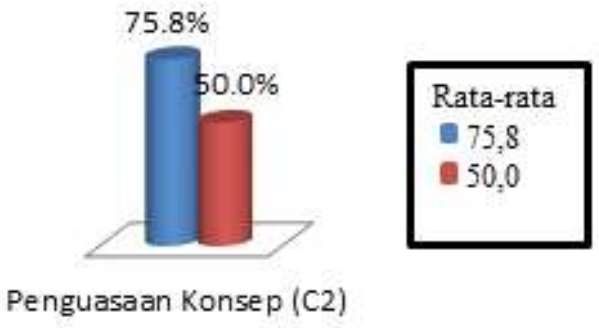

Gambar 1. Penguasaan Konsep Siswa Kelas Eksperimen dan Kontrol

Hasil perhitungan uji normalitas diperoleh bahwa nilai signifikansi (Asymp. Sig 2-tailed) kelas eksperimen adalah 0,080 dan kelas kontrol sebesar 0,080. Hal ini menyatakan bahwa nilai signifikansi kelas eksperimen dan kelas kontrol keduanya memiliki nilai lebih besar dari $\alpha=0,05$ sehingga $\mathrm{H}_{0}$ diterima yang berarti bahwa data berdistribusi normal. $\mathrm{t}_{\text {hitung }}$ berada pada daerah penolakan $\mathrm{H}_{0}$ maka $\mathrm{H}_{0}$ ditolak. Jadi antara kelas eksperimen dan kelas kontrol menunjukkan perbedaan nilai yang signifikan. Nilai penguasaan konsep yang belajar menggunakan metode field trip lebih tinggi dari pada nilai siswa pada kelas yang belajar dengan metode ceramah.

Berdasarkan hasil analisis, terdapat perbedaan nilai hasil penguasaan konsep siswa yang memanfaatkan mangrove Cagar Alam Pulau Dua. "A one-day field trip for both improving students' knowledge in ecology and forexamining short-term effects" (Prokop et al. 2007). Hal ini dapat dilihat dari perbandingan pada kelas eksperimen yang melakukan field trip di Cagar Alam Pulau Dua memiliki skor dan nilai yang lebih tinggi dibandingkan siswa kelas kontrol yang hanya melakukan kegiatan pembelajaran ceramah dan diskusi di dalam kelas. Hasil t-test menunjukkan bahwa uji thitung $(6,913)>\mathrm{t}$ tabel (31;0,025 adalah 2.040), maka $\mathrm{H}_{0}$ ditolak, dengan signifikansi Sig (2-tailed) $(0,000)<(0,025)$ maka $\mathrm{H}_{0}$ ditolak. Jadi antara kelas eksperimen dan kelas kontrol terdapat perbedaan nilai penguasaan konsep yang signifikan.

Hasil skor penguasaan konsep (memahami) siswa pada kelas eksperimen lebih tinggi dari siswa kelas kontrol. Jika dilihat dari nilai ratarata hasil penguasaan konsepnya, siswa pada kelas eksperimen nilai rata-ratanya adalah 75,8; sedangkan nilai rata-rata siswa kelas kontrol adalah 50. Hal ini dapat disebabkan oleh penguasaan siswa saat proses pembelajaran berlangsung dimana siswa menemukan dan membentuk konsep baru saat melakukan field trip mangrove Cagar Alam Pulau Dua. Faktafakta yang siswa lihat dari awal pengamatan serta permasalahan pencemaran yang terjadi pada kawasan hutan mangrove membuat siswa berpikir dan mulai untuk menemukan sebuah konsep baru tentang pencemaran lingkungan. Senada dengan (Stavy dalam Fensham, 1994) ' human beings construct their knowledge by a continous process of interaction between the individual's cognitive system and his/her physical and cultural environtment'.

Perkembangan konsep yang diperoleh setiap siswa akan berbeda-beda, salah satunya dapat dilihat dari hasil tes penguasaan konsep yang diujikan.

Penguasaan siswa dalam menjawab dan mendefinisikan sebuah konsep atau istilah yang terkait dengan pencemaran lingkungan pada kelas eksperimen dan kelas kontrol berbeda-beda. Senada dengan (Stavy dalam Fensham at al., 1994) "the development of concepts can be studied from children's explanation or definition of the concepts". Hasil tes penguasaan konsep siswa menunjukkan bahwa pada kelas eksperimen 69\% siswa telah mampu melewati batas nilai KKM, sedangkan pada kelas kontrol hanya $12,5 \%$ siswa yang mampu melewati batas nilai KKM. Hal ini menunjukkan bahwa terdapat perbedaan nilai hasil penguasaan konsep pada siswa yang melakukan kegiatan field trip mangove di Cagar Alam Pulau Dua. 
Selain dari hasil tes penguasaan konsep siswa, pemanfaatan potensi lokal Cagar Alam Pulau Dua juga dapat dilihat dari tanggapan siswa terhadap metode field trip dalam pembelajaran pencemaran lingkungan. Hasil tanggapan menunjukkan bahwa kunjungan lapangan Cagar Alam Pulau Dua merupakan cara belajar yang menarik dan menyenangkan bagi siswa karena dapat menambah wawasan dan informasi baru mengenai masalah lingkungan mangrove yang tercemar. Siswa juga menjadi lebih mudah memahami tentang materi pencemaran karena siswa melihat keadaaan lingkungan secara langsung. Pembelajaran dengan metode field trip merupakan suatu cara penguasaan bahan pelajaran oleh siswa dengan membawa langsung siswa ke objek lingkungan kehidupan nyata agar siswa dapat mengamati dan memperoleh pengalaman secara langsung (Djamarah, 2005).

Pada kelas eksperimen nilai penguasaan konsep lebih tinggi dari pada kelas kontrol. Pada kelas eksperimen $75,8 \%$ siswa mampu menguasai konsep, sedangkan pada kelas kontrol hanya $50 \%$ siswa yang mampu menguasai konsep. Menurut Dahar (2011) penguasaan konsep merupakan kemampuan siswa dalam memahami makna secara ilmiah baik teorimaupun penerapannya dalam kehidupan sehari-hari. Penguasaan konsep yang dilihat adalah kemampuan siswa dalam memahami konsep yang telah dipelajari. Menurut Sudjana (2006) pemahaman adalah tingkat kemampuan yang mengharapkan siswa mampu memahami arti dari konsep, situasi, serta fakta yang diketahuinya, siswa tidak hanya menghafal secara verbalitas, tetapi memahami konsep dari konsep atau masalah.

Pemahaman konsep siswa kelas eksperimen lebih tinggi dari siswa kelas kontrol. Hal ini dapat dikarenakan siswa pada kelas eksperimen melihat objek dan fakta-fakta pencemaran lingkungan sehingga dapat lebih memahami situasi dan mampu menghubungkan fakta-fakta tersebut dengan konsep yang telah dipelajari terlebih dahulu. Konsep-konsep yang abstrak akan lebih mudah dipahami oleh siswa jika siswa mengalami pembelajaran secara langsung (Komalasari, 2011).

Siswa setelah melaksanakan field trip mampu menguraikan permasalahanpermasalahan yang ditemui lalu menghubungkannya dengan fakta yang diperoleh di lapangan dari konsep awal yang telah diperolehnya, siswa juga mampu membedakan karaktersitik hewan dan tumbuhan pada daerah mangrove yang tercemar dan alami, siswa mampu mengkontruksi pemikiran awal yang diperolehnya hanya dari buku mengenai pencemaran lingkungan. Siswa mampu memahami dan menjelaskan kembali konsep-konsep pencemaran lingkungan yang telah dipelajarinya dan menyesuaikannya dengan keadaan nyata yang dilihatnya pada mangrove Cagar Alam Pulau Dua. Siswa dikatakan memahami bila siswa dapat mengkontruksi makna dari pesan-pesan pembelajaran, baik secara lisan maupun tulisan (Anderson \& Krathwohl, 2010).

Pada kelas kontrol pemahaman konsep siswa lebih rendah dari kelas eksperimen. Hal ini dapat dikarenakan siswa pada kelas kontrol hanya diberikan konsep-konsep yang disampaikan secara singkat dan cepat oleh guru saat ceramah, sehingga siswa hanya mampu mengingat tanpa bisa lebih dalam untuk memahami, mengaplikasikan dan menganalisis informasi yang disampaikan guru. Materi yang dikuasai siswa terbatas hanya pada apa yang telah dikuasai dan disampaikan guru.

Pada metode ceramah siswa hanya mendengarkan penjelasan - penjelasan yang disampaikan oleh guru, meskipun adakalanya guru mencoba untuk melakukan interaksi dengan siswa dengan bertanya kepada siswa atau sebaliknya meminta siswa untuk bertanya. Namun tetap saja dengan metode ceramah, guru hanya mampu memvisualisasikan fakta, gagasan, 
kejadian, dan peristiwa dalam bentuk tiruan atau abstrak dari keadaan yang sebenarnya sehingga penguasaan siswa dalam menganalisis lebih rendah. Pada materi pencemaran lingkungan siswa hanya belajar melalui buku bacaan dan penjelasan yang disampaikan oleh guru, tanpa siswa mengetahui secara nyata bentuk pencemaran yang terjadi di lingkungan sekitar. Proses belajar mengajar pada hakikatnya adalah proses komunikasi dalam penyampaian pesan dan adakalanya proses penyampaian pesan tersebut mengalami salah penafsiran yang menyebabkan kegagalan dalam memahami apa yang didengar, dibaca, atau dilihat serta diamati (Sadiman et al, 2009).

\section{SIMPULAN}

Berdasarkah hasil penelitian dapat disimpulkan bahwa penggunaan metode field trip pada mangrove Cagar Alam Pulau Dua terhadap penguasaan konsep siswa pada konsep pencemaran lingkungan lebih tinggi dari kelas kontrol dan potensi lokal mangrove Cagar Alam Pulau Dua dapat dijadikan sebagai salah satu sumber belajar bagi siswa pada konsep pencemaran lingkungan.

\section{DAFTAR RUJUKAN}

Anderson, L. W. \& Krathwohl, D.R. 2010. Kerangka Landasan untuk pembelajaran, Pengajaran, dan Asesmen. Yogyakarta: Pustaka Pelajar
Aqib, Z., \& Rohmanto, E. 2007. Membangun Profesionalisme Guru dan Pengawas Sekolah. Bandung: CV. YramaWidya.

Dahar, R. W. 2011. Teori-Teori Belajar dan Pembelajaran. Jakarta: Erlangga.

Djamarah, S. 2005. Guru dan Anak Didik dalam Interaksi Edukatif. Jakarta: Rineka Cipta.

Fensham, Gunstone, \& White. 1994. Pedagogical Sequence and Teaching Strategies Based on Cognitive Research. London: The Falmer Press.

Komalasari, K. 2011. Pembelajaran Kontekstual Konsep dan Aplikasi. Bandung: PT RefikaAditama.

Prokop, Tuncer, \& Kvasnic. 2007. ShortTerm Effects of Field Programme on Students' Knowledge and Attitude Toward Biology: a Slovak Experience. Journal of Science Education and Technology, 16, (3).

Sadiman, Raharja, Haryono, \& Rahardjito. 2009. Media Pendidikan. Jakarta: PT Rajagrafindo Persada.

Sudjana, N. 2006. Penilaian Hasil Proses Belajar Mengajar. Bandung: PT. Remaja Rosdakarya

Takandjandji, M. \& Kwatrina, R.T. 2011. Pengelolaan Cagar Alam Pulau Dua di Provinsi Banten sebagai Ekosistem Bernilai Penting. Jurnal Penelitian Hutan dan Konservasi Alam, 8 (2) 112. 